\title{
ZARZĄDZANIE INFORMACJĄ W PROCESACH DECYZYJNYCH ORGANIZACJI
}

\begin{abstract}
Społeczeństwo, w którym obecnie żyjemy, społeczeństwo informacyjne, odzwierciedla najważniejszą cechę przemian społecznych i gospodarczych, czyli procesy tworzenia i gromadzenia informacji. Współcześnie informacja jest najważniejszym zasobem, a jej tworzenie, gromadzenie i przekazywanie jest określane jako zasadnicza działalność społeczno-gospodarcza. Wzrost znaczenia informacji jako zasobu ekonomicznego i składnika konkurencyjności powoduje, że informacja stała się niezbędna dla sprawnego funkcjonowania i rozwoju organizacji. Wartościowa i pozyskana we właściwym czasie informacja zwiększa pewność w podejmowaniu trafnych decyzji.

Decydentom najczęściej najwięcej czasu zabiera praca nad informacjami. Często kierownik jest nietrafnie poinformowany $\mathrm{z}$ powodu nadmiaru informacji. $\mathrm{W}$ obszarze zarządzania newralgicznym punktem okazuje się nie wytwarzanie, przechowywanie i przekazywanie informacji, lecz jej analizowanie i filtrowanie.

Komunikowanie rozpatruje się jako jedną z najistotniejszych faz cyklu zarządzania Rozumianą jako prawidłowy obieg informacji wewnątrz organizacji oraz jej wymianę $\mathrm{z}$ otoczeniem. Komunikowanie łączy się ze wszystkimi elementami zarządzania, a skuteczne komunikowanie zapewnia osiągnięcie celów organizacji.

Proces decyzyjny zachodzi w systemie często nazywanym systemem informacyjno-decyzyjnym. Ponieważ obejmuje wszystkie procesy dostarczania decydentom właściwych, terminowych i potrzebnych informacji, które umożliwiają podejmowanie decyzji mających wpływ na sprawność funkcjonowania organizacji.

Celem artykułu jest próba usystematyzowania problematyki zarządzania informacjami $\mathrm{w}$ organizacji. Artykuł zawiera podstawowe pojęcia związane z informacją i komunikacją $\mathrm{w}$ procesach decyzyjnych organizacji. Zaprezentowano w nim rolę informacji w zarządzaniu oraz wybrane aspekty zarządzania informacjami.
\end{abstract}

Słowa kluczowe: informacja, komunikowanie, zarządzanie, zarządzanie informacją.

\section{WPROWADZENIE}

Naturę informacji próbuje się wyjaśnić w różnych dyscyplinach, między innymi cybernetyce, teorii systemów i naukach o zarządzaniu analizując jej miejsce w procesach podejmowania decyzji. Wielu autorów uważa, że pełne wyjaśnienie terminu informacji jest możliwe po uwzględnieniu czterech podstawowych aspektów: semantycznego, ilościowego, jakościowego i pragmatycznego.

Pojęcie ,informacja” wywodzi się od łacińskiego informatio i znaczy „wyobrażenie, wyjaśnienie, zawiadomienie"; potocznie oznacza każdą wiadomość. Słowo informatio w starożytnej łacinie określało nadawanie formy, kształtowanie, instruowanie, nauczanie,

${ }^{1}$ Dr Waldemar Krztoń, adiunkt, Zakład Nauki o Bezpieczeństwie, Wydział Zarzadzania, Politechnika Rzeszowska, Al. Powstańców Warszawy 8, 35-959 Rzeszów; e-mail: wkrzton@ prz.edu.pl. 
formułowanie umysłu ${ }^{2}$. Od informacji odróżnia się dane, które są elementami informacji, ale rozpatrywane osobno nie mają wartości informacyjnej. Połączenie danych pozwala nadać im postać informacji.

W klasycznym stosunku do organizacji zwanym podejściem decyzyjnym informacja postrzegana jest jako odwzorowanie przeszłości, teraźniejszości i przyszłości. Łączy się ją z procesami identyfikacji, uważając ją za miarę złożoności i różnorodności oraz czynnik sprawczy, sterujący ${ }^{3}$. W takim ujęciu informacja jest elementem, który opisuje rzeczywistość, definiuje pojęcia i ułatwia skuteczne działanie.

Definicje występujące w literaturze przedmiotu, zdaniem Janusza Czekaja, wskazują, że informacja stanowi określoną prezentację zdarzeń, stanów rzeczy, obiektów itp. z perspektywy przeszłości, teraźniejszości lub przyszłości. Jej strukturę tworzą cztery elementy, a mianowicie: treść, nośnik, symbol, za pomocą którego informacja jest utrwalana, oraz sposób jej przenoszenia ${ }^{4}$. Informacja może odnosić się do przedmiotów, zjawisk i wydarzeń, może istnieć niezależnie od rzeczy, których dotyczy. Jest zawsze w jakiś sposób wyrażana, najczęściej za pomocą kodu, dzieli się także na mniejsze fragmenty, czyli wiadomości lub komunikaty. Przy pomocy stosownych środków może się przenosić w przestrzeni i czasie. Przenoszenie informacji w przestrzeni określa się mianem przekazu informacji, zaś przenoszenie w czasie - gromadzeniem lub magazynowaniem ${ }^{5}$. Bogdan Stefanowicz po analizie podstawowych własności informacji uważa, że:

1) informacja jest pojęciem niematerialnym, a jej ujawnienie wymaga danych;

2) w ujęciu infologicznym można ją traktować jako relację;

3) istnieje niezależnie od subiektywnego odbioru, a więc jest obiektywna;

4) ma różne znaczenie dla różnych odbiorców;

5) jest odzwierciadleniem pewnej cechy obiektu lub wycinkowym jego opisem;

6) stanowi model określonego wycinka rzeczywistości;

7) przejawia cechę synergii;

8) jest łączona przez odbiorców ze znanymi im innymi informacjami;

9) mimo że nie jest energią, podlega ilościowemu pomiarowi;

10) wykazuje się różnorodnością, wynikającą z odmienności rozpatrywanych obiektów, rozmaitości źródeł, subiektywizmu interpretacyjnego odbiorców;

11) podlega powielaniu i przenoszeniu w czasie i przestrzeni, a także przetwarzaniu, nie ulega zniszczeniu, lecz najwyżej zniekształceniom i deformacjom;

12) jest zasobem niewyczerpalnym, co wynika z możliwości jej powielania, nieskończonej liczby obiektów i ich nieskończonej złożoności;

13) pozyskiwanie, przechowywanie, przesyłanie i udostępnianie informacji wymaga określonych kosztów;

14) rozkład informacji w otoczeniu jest nierównomierny, co wywołuje jej asymetrię, czyli niejednakową dostępność dla różnych odbiorców ze względu na źródła i koszty jej pozyskania, preferencje w ustalaniu faktów i inne czynniki ${ }^{6}$.

\footnotetext{
${ }^{2}$ C. Berman, Informacja i aspekty komunikacji, „Zagadnienia Naukoznawstwa” 1991, nr 3-4, s. 429.

3 J. Oleński, Standardy informacyjne w gospodarce, Warszawa 2000, s. 15.

4 J. Czekaj (red.), Podstawy zarządzania informacją, Kraków 2012, s. 15.

5 T. Kasprzyk (red.), Cybernetyka zarzadzania w systemach ekonomicznych, Warszawa 1971, s. 61.

${ }^{6}$ B. Stefanowicz, Informacja, Warszawa 2010, s. 32-37.
} 
Niektórzy uczeni rozumieją informację dwojako: po pierwsze przede wszystkim jako proces, w wyniku którego jest się poinformowanym, po drugie jako rezultat jakiegoś procesu informacyjnego (produkt) ${ }^{7}$. Najczęściej informacja związana była z wytworem materialnym, obecnie coraz częściej informacja jest produktem albo pożądaną przez użytkownika usługą (płyta kompaktowa, Internet).

Reasumując można uznać, że informacja różnie jest postrzegana, m.in. jako środek materialny (dobro), jako niezbędny element w czasie podejmowania prawidłowych decyzji lub czynnik produkcji.

\section{KOMUNIKACJA INTERPERSONALNA}

Pojęcie komunikacja wywodzi się od łacińskiego słowa communicatio, które oznacza użyczenie, doniesienie, dotyczy rzeczy, a nie osób. Jako źródło słowa komunikacja uważa się też słowo communis, oznaczające wspólny, powszechny, ogólny. Informacja z określonego źródła musi być w pewien sposób dostarczona do odbiorcy. Proces przekazywania informacji pomiędzy nadawcą i odbiorcą nazywa się komunikacją. Proces ten przebiega w dwóch kierunkach ${ }^{8}$. Ludzie przekazują informację za pomocą różnych środków komunikacji: od mimiki twarzy, gestów, dźwięków, po mowę i pismo. Komunikacja jest elementem niezbędnym do funkcjonowania każdej organizacji, wpływa na potrzeby ludzkie oraz decyduje o panujących stosunkach w danej społeczności.

Komunikacja interpersonalna to wymiana informacji między nadawcą i odbiorcą, przy czym przekaz treści następuje za pośrednictwem jakiegoś kanału. Zakłada się, że przekazana informacja (komunikat) ma wpłynąc na zmianę zachowania odbiorcy ${ }^{9}$. O wyborze kanału decydują wymagania i potrzeby odbiorcy, jak również ważność przekazywanej informacji. Kanały przesyłania informacji charakteryzują się różną sprawnością. W przekazach niewerbalnych uwaga koncentruje się na nadawcy, a więc ważna jest intencja nadawcy oraz sposób formułowania komunikatu. Na skuteczne porozumiewanie się ma wpływ poziom wiedzy nadawcy, doświadczenie, prestiż, jego przekonania, a także indywidualny punkt widzenia na przekazywaną informację. Z kolei komunikacja niewerbalna pomaga odczytać prawdziwe intencje nadawcy i jego emocje ${ }^{10}$. Komunikowanie, w przeciwieństwie do informowania, charakteryzuje się celem przekazu i sprzężeniem zwrotnym.

\section{KOMUNIKACJA W ORGANIZACJI}

Wyróżnia się trzy główne typy działalności informacyjnej, do której należą:

1) przechowywanie informacji - działanie statyczne, w czasie którego informacja nie powinna ulegać zmianom. Odbywa się przy wykorzystaniu jakiegoś obiektu mającego charakter materialny (przechowalnika informacji);

\footnotetext{
7 Z. Martyniak (red.), Elementy zarządzania informacja i komunikacja w przedsiębiorstwie, Kraków 1997, s. 6.

${ }^{8}$ M. Pańkowska, Wiedza i komunikacja $w$ innowacyjnych organizacjach. Komunikacja elektroniczna, Katowice 2011, s. 373.

9 W. Okoń, Stownik pedagogiczny, Warszawa 1992, s. 94.

${ }^{10}$ S. Wojciechowska-Filipek, Zarzadzanie jakościa informacji w organizacji zhierarchizowanej, Warszawa 2015, s. 39.
} 
2) przetwarzanie informacji - przekształcanie zbioru informacji w inny zbiór informacji, najczęściej według z góry określonego algorytmu, często w celu uzyskania możliwości wyciągania wniosków lub uwypuklenia treści zawartej w pierwotnej informacji, które były trudne do wychwycenia. Może polegać także na samym porządkowaniu lub klasyfikowaniu informacji;

3) przesyłanie informacji - wszelkie przemieszczenie informacji od nadawcy do odbiorcy (ze względu na fakt, iż informacja istniejąca u nadawcy ma inną postać niż informacja przekazywana przez ogniwa kanału łączności, musi zostać przed nadaniem zakodowana, a po odbiorze - odkodowana $)^{11}$.

Model zarządzania informacją w przedsiębiorstwie (sformułowany przez H. Lescę) $)^{12}$ dzieli informację według kryterium celu, a strumienie informacyjne ${ }^{13}$ ze względu na źródło i przeznaczenie informacji, wskazując na wstępujące pomiędzy nimi zależności. Autor tego modelu wyszczególnia ,informacje działalności” oraz ,informacje współdziałania”. „Informacja działalności” jest sformalizowana, powinna zapewnić sprawne funkcjonowanie i realizację celów przedsiębiorstwa. „Informacja współdziałania” jest formalna lub nieformalna, kształtuje więzi i zachowania organizacyjne w przedsiębiorstwie oraz relacje przedsiębiorstwa z otoczeniem. Wymianę informacji działalności nazywa się informowaniem, natomiast wymianę informacji współdziałania obejmującą sprzężenie zwrotne komunikowaniem ${ }^{14}$.

Komunikowanie w zarządzaniu to proces organizacyjny polegający na wymianie informacji pomiędzy różnymi podmiotami, który łączy ze sobą jednostki organizacyjne firmy i firmę z otoczeniem. Arkadiusz Potocki uznaje, że komunikowanie się jest „,niezbędnym warunkiem istnienia przedsiębiorstwa, zapewniając łączność z jego otoczeniem oraz między jego jednostkami organizacyjnymi, przy czym łączność rozumiana jest przede wszystkim jako możliwość celowego przekazywania informacji"15.

Komunikowanie wymienia się jako jedną z istotnych cech zarządzania, która definiowana jest jako prawidłowy obieg informacji wewnątrz organizacji oraz jej wymianę z otoczeniem. Komunikowanie łączy się ze wszystkimi funkcjami zarządzania (planowanie, organizowanie, motywowanie, kontrolowanie), skuteczne zapewnia osiągnie celów. Organizacja funkcjonuje w określonym otoczeniu i choć strukturalnie jest z niego wyodrębniona, to nie jest wyizolowana. Zarówno organizacja oddziałuje na otoczenie, jak i odwrotnie, co jest możliwe jedynie dzięki procesom komunikowania.

Komunikowanie w organizacji ograniczone jest strukturą systemu zarządzania określającą hierarchię organizacyjną - stosunki nadrzędności i podrzędności. Wyróżnia się komunikowanie pionowe (wertykalne), a w jego ramach komunikowanie „w dół” i „w górę”, oraz komunikowanie poziome (horyzontalne) ${ }^{16}$. Komunikowanie pionowe

${ }^{11}$ S. Forlicz, Informacja w biznesie, Warszawa 2008, s. 14-15.

12 E. Lesca, H. Lesca, Gestion de Information, Paris 1995.

${ }^{13}$ Strumień informacyjny to systematycznie (cyklicznie) powtarzający się przepływ informacji. Zob. B. Stefanowicz, Informacyjne systemy zarzadzania. Przewodnik, Warszawa 2007, s. 93. Strumień informacyjny to przepływ semantycznie jednorodnej informacji w ramach instytucji lub między instytucjami. Zob. W. Flakiewicz, Informacyjne systemy zarzadzania. Podstawy budowy i funkcjonowania, Warszawa 1990, s. 73.

${ }_{14}$ Z. Martyniak (red.), Elementy zarzadzania informacją..., s. 6.

15 A. Potocki, R. Winkler, A. Żbikowski, Techniki komunikacji w organizacjach gospodarczych, Warszawa 2003, s. 35.

16 J. Stankiewicz, Komunikowanie się w organizacji, Wrocław 1999, s. 19-20. 
odbywa się w górę i w dół wzdłuż linii podporządkowania w organizacji i obejmuje relacje zwierzchnik - podwładny. Jego celem jest przekazywanie poleceń od kierownictwa oraz zbieranie informacji od podwładnych. Charakterystyczne przykłady informacji przekazywanych w linii komunikowania pionowego to nakazy, zalecenia, wskazówki do dołu oraz wnioski, sprawozdania, prośby, odpowiedzi w górę. Komunikowanie poziome obejmuje osoby na równorzędnych lub zbliżonych stanowiskach w hierarchii organizacji (ten sam szczebel struktury organizacyjnej), albo z tego samego szczebla zarządzania z różnych jednostek organizacyjnych. Ma na celu koordynację wykonywanych zadań, a także rozwiazywanie zaistniałych problemów.

\section{INFORMACJA W PROCESIE DECYZYJNYM}

Zarządzanie organizacją polega na bezustannym dokonywaniu wyborów. Takie podejście oznacza rozpatrywanie procesu kierowania jako szczególnego przypadku zorganizowanego działania i wykonywania zróżnicowanych pod rozmaitym względem funkcji kierowniczych, ale także jako ciągłego procesu podejmowania decyzji ${ }^{17}$. W takim znaczeniu kierowanie polega na stałym przetwarzaniu informacji, czego rezultatem są podejmowane decyzje ${ }^{18}$.

W literaturze przedmiotu można spotkać wiele rodzajów decyzji; podział stosowany jest w oparciu o różne kryteria. Kryterium podziału ze względu na:

1) zasięg, wagę, istotność, horyzont czasowy:

- strategiczne (najwyższej wagi);

- taktyczne (niższy stopień istotności);

- operacyjne (dotyczące bieżących celów).

2) stopień ryzyka:

- decyzje podejmowane w warunkach pewności;

- decyzje podejmowane w warunkach ryzyka;

- decyzje podejmowane w warunkach niepewności.

3) stopień innowacyjności:

- rutynowe (powtarzalne);

- adaptacyjne (dostosowawcze);

- innowacyjne (zmieniające warunki);

- regresywne (cofające się w przeszłość).

4) programowalność:

- programowalne (zazwyczaj rutynowe);

- nieprogramowalne (o dużym stopniu ryzyka).

5) struktura rozwiązywanego problemu:

- selekcyjne;

- alokacyjne;

- rankingowe.

6) liczba decydentów:

- samodzielne;

- grupowe (kolektywne).

17 J. Kurnal, Zarys teorii organizacji zarzadzania, Warszawa 1969, s. 368.

${ }^{18}$ H. Simon, Podejmowanie decyzji kierowniczych. Nowe nurty, Warszawa 1982, s. 70. 
7) stopień realizacji celów:

- zadowalające;

- optymalne ${ }^{19}$.

Organizację często postrzega się jako system podejmowania decyzji i przetwarzania informacji. Wynika to z kilku kwestii:

1) informacja jest tworzywem, z którego powstaje decyzja;

2) podjęta decyzja jest informacją dla decyzji późniejszych;

3) decyzja jest pewnym typem informacji - oprócz tego, że umożliwia poznanie rzeczywistości, stanowi czynnik sprawczy stanu rzeczy, faktów, spraw, które będą miały miejsce w przyszłości ${ }^{20}$.

$\mathrm{W}$ procesie decyzyjnym występuje ciąg procesów będących transformacjami informacji, które odpowiadają fazom procesu decyzyjnego takim jak: analiza, sformułowanie problemu, rozwiązanie problemu i podjęcie decyzji. Wielu uczonych uważa, że istotą zarządzania jest tworzenie sieci komunikacji, co oznacza podejmowanie decyzji, ustalenie różnych celów i negocjacje do czasu osiągnięcia celu. Potwierdzeniem tego może być definicja, według której zarządzanie polega przede wszystkim na decydowaniu (lub współdecydowaniu) o misji i celach organizacji, o kierunkach i sposobach wykorzystania zasobów organizacji - ludzkich, rzeczowych, finansowych, informacyjnych ${ }^{21}$. Inni autorzy zarządzanie określają jako zespół działań decyzyjnych zapewniających sterowanie procesami i zasobami firmy w celu takiego ich powiązania i wykorzystania, aby w sposób sprawny, skuteczny i zgodny ze społecznym usprawnieniem działań gospodarczych uzyskać możliwie najlepszy efekt w istniejących warunkach funkcjonowania (prawnych, ekonomicznych, społecznych) ${ }^{22}$. Niektórzy autorzy uważają termin ,,podejmowanie decyzji” za synonim zarządzania ${ }^{23}$. Istotą natomiast jest podejmowanie decyzji na każdym szczeblu zarządzania, zaczynając od określenia celów aż do ich osiągnięcia.

Decyzja to świadomy wybór jednego z wielu wariantów. Jest efektem myślenia i procesu umysłowego, natomiast charakterystyczne dla niej jest to, że wykorzystuje informacje z przeszłości i teraźniejszości, a wykonanie jej następuje w przyszłości.

Proces decyzyjny tworzy logiczny układ następujących po sobie, zależnych od siebie etapów. W klasycznym rozumieniu rozpoczyna się od zdefiniowania celu, zebrania odpowiednich informacji (informacja adekwatna i informacja dostępna, ale pełna i dokładna), po czym następuje opracowywanie możliwych wariantów działania, po którym podejmowana jest decyzja i w końcu następuje jej wprowadzanie w życie i ocena ${ }^{24}$. W tzw. modelu menadżerskim proces decyzyjny jest bardziej praktyczny i składa się z następujących etapów:

1) dostrzeżenie i sformułowanie problemu;

2) zbieranie informacji określających jego istotę i umożliwiających jego całościową analizę - informacje mogą być niepełne, niedoskonałe;

3) przetwarzanie informacji i proponowanie alternatywnych rozwiązań problemu;

4) ocena alternatyw i wybór najlepszego z możliwych wariantu;

\footnotetext{
19 A. Nowicki, M. Sitarska, Procesy informacyjne w zarzadzaniu, Wrocław 2010, s. 23.

20 J. Czekaj (red.), Podstawy zarzadzania..., s. 28.

${ }^{21}$ A. Czermiński, M. Czerska (i in.), Zarządzanie organizacjami, Toruń 2001, s. 87.

22 E. Weiss (red.), Podstawy i metody zarzadzania. Wybrane zagadnienia, Warszawa 2008, s. 103.

23 J. Penc, Sztuka skutecznego zarzadzania, Kraków 2005, s. 108.

${ }^{24}$ J. Adair, Podejmowanie decyzji, Warszawa 1998, s. 23.
} 
5) sprawdzenie w fazie realizacji, czy przyjęte rozwiązanie daje zamierzone efekty (obserwacja i korekta) ${ }^{25}$.

Proces decyzyjny można także rozpatrywać w szerokim i wąskim znaczeniu. W szerokim znaczeniu jest to złożony proces, na który składają się:

1) rejestracja i ocena informacji;

2) identyfikacja problemu decyzyjnego;

3) formułowanie i ocena wariantów decyzyjnych;

4) przewidywanie skutków decyzji;

5) zastosowanie przyjętego kryterium wyboru;

6) określenie i wydanie decyzji;

7) rejestracji informacji o jej wykonaniu ${ }^{26}$.

W wąskim znaczeniu podejmowanie decyzji to tylko jeden z kroków całego procesu decyzyjnego i oznacza świadomy akt woli decydenta dokonującego nielosowego wyboru jednego ze zbioru możliwych wariantów rozwiązania problemu decyzyjnego ${ }^{27}$.

Informacja jest podstawą procesu decyzyjnego, ponieważ proces decyzyjny opiera się na informacji niezbędnej dla właściwych rozstrzygnięć. Dlatego też często proces decyzyjny określny jest procesem informacyjno-decyzyjnym. W organizacji proces informacyjno-decyzyjny odbywa się w trzech obszarach:

1) jako relacje wewnątrz organizacji, kiedy zachodzi obieg wewnętrzny informacji i decyzji;

2) jako relacje zewnętrzne miedzy instytucjami powiązanymi organizacyjnie polegające na informowaniu zwierzchnika i otrzymaniu od niego dyspozycji oraz wypełnianie tych samych funkcji w stosunku do instytucji niższego szczebla;

3) jako relacje zewnętrzne $\mathrm{z}$ instytucjami obcymi, nie związanymi organizacyjnie również polegające na informowaniu i otrzymywaniu informacji i decyzji ${ }^{28}$.

Na strukturę i prawidłowe funkcjonowanie organizacji znaczący wpływ wywierają informacja i komunikowanie. Wszystkie aspekty płaszczyzny działania organizacji zależą od charakteru przetwarzanej informacji. Wartość i miejsce informacji należy łączyć i analizować równolegle z procesami zarządzania, produkcji, usług i innych. Można stwierdzić, że bez właściwego rodzaju zasobu informacji organizacja nie może funkcjonować.

Zasób informacyjny obejmuje uporządkowany zestaw danych, wiadomości i wiedzy zebranych w celu ich przetwarzania i otrzymania nowej jakościowo informacji o określonym obszarze funkcjonowania organizacji ${ }^{29}$. To zbiór różnych informacji potencjalnie użytecznych do prowadzenia działalności przez finalnych użytkowników ${ }^{30}$. Informacja stała się niezbędnym elementem organizacji. Czynnikami kształtującymi wartość organizacji stały się informacja i systemy informacyjne wytwarzające, gromadzące i przetwarzające olbrzymie ilości informacji.

25 R. Krupski, Podstawy organizacji i zarzadzania, Wałbrzych 1997, s. 16.

26 W.K. Roman, Podstawy zarzadzania informacją, Toruń 2012, s. 57.

27 A. Stabryła, J. Trzcieniecki, Organizacja i zarządzanie. Zarys problematyki, Warszawa 1986, s. 194.

${ }^{28}$ W.K. Roman, Podstawy..., s. 57.

29 A. Adamczyk, A. Jurga, J. Kałkowska i in., Projektowanie systemów informacyjnych zarząaania, Poznań 2010, s. 34.

${ }^{30}$ K. Materska, Informacja w organizacjach społeczeństwa wiedzy, Warszawa 2007, s. 55. 
Posiadanie informacji daje przewagę nad konkurencją, dlatego informacja zaliczana jest do zasobów strategicznych organizacji. Informacja jest zasobem niepowtarzalnym i nie można go zastąpić przez inne zasoby: wspiera różne procesy, umożliwia komunikację pracowników i kierownictwa, zwiększa wiedzę pracowników, pomaga podejmować decyzje, ułatwia kontakty z otoczeniem.

Informacja dla zarządzania nazywana jest informacją zarządczą, która jest szczególnym rodzajem informacji umożliwiającej realizację podstawowych funkcji zarządzania: planowania, organizowania, motywowania i kontrolowania. Jest zawsze powiązana z jedną z funkcji zarządzania i pozwala podejmować decyzje na różnych szczeblach zarządzania. Jest narzędziem zarządzania, charakteryzującym się aktualnością, użytecznością i zrozumiałością dla odbiorcy. Powinna być dokładna i precyzyjna, dzielona jest według różnych kryteriów:

1) poziomów zarządzania - na informacje operacyjne, taktyczne i strategiczne;

2) spełnianych funkcji - na poznawcze, decyzyjne i wykonawcze;

3) roli w zarządzaniu organizacją - na planistyczne, organizacyjne, kontrolne, koordynacyjne;

4) stopnia formalności - na informacje formalne i nieformalne;

5) wpływu na podejmowane decyzje - inspirujące proces podejmowania decyzji, zasilające i uzupełniające kolejne etapy procesu decyzyjnego, podające do wiadomości wynik działań;

6) treść i przeznaczenie - gospodarcze, naukowe, specjalistyczne ${ }^{31}$.

Dla potrzeb planowania niezbędne będą informacje z zakresu teorii prognozowania i planowania, teorii trendów rozwojowych, teorii rozwiązywania problemów decyzyjnych. $\mathrm{W}$ organizowaniu potrzebne będą informacje $\mathrm{z}$ zakresu nauki o organizacji, zasadach gospodarowania. Z kolei dla funkcji motywowania konieczne będą informacje o zarządzaniu, teorii motywowania, roli kar, gróźb i nagród. Funkcja kontrolowania wymaga informacji z zakresu zasad, sposobów, wymogów, metod i technik badania kontrolnego.

Zasoby informacyjne w organizacji można dzielić według różnych kryteriów:

1) miejsca w procesie przetwarzania - będą to zasoby informacyjne wejściowe i wyjściowe;

2) stopnia przetworzenia - zasoby informacyjne źródłowe (pierwotne), pośrednie, wynikowe, pochodne, wtórne;

3) typu i formy - zasoby informacyjne tekstowe, liczbowe, multimedialne;

4) opisu zjawiska, do którego się odnoszą - zasoby informacyjne porządkujące, klasyfikujące, identyfikujące;

5) poziomu zmienności - zasoby informacyjne stałe, zmienne ${ }^{32}$.

Obecnie często wykorzystuje się zasoby informacyjne Internetu. Stanowią je dane, informacje, techniki informacyjne posiadające wymierną wartość, które mogą zostać użyte do produkcji, usługi lub zwiększenia posiadanej wiedzy. Są to min. zbiory aktów prawnych, rejestry publiczne, Biuletyn Informacji Publicznej, zasoby różnego rodzaju archiwów. Zasoby informacyjne Internetu mają swoje charakterystyczne cechy:

1) różne źródła pochodzenia;

2) architektura (logiczny podział treści, np. na stronie WWW);

3) trwałość (nie giną w sieci, mogą być dostępne dla każdego lub uprawnionego);

${ }^{31}$ W.K. Roman, Podstawy..., s. 57.

32 A. Adamczyk, A. Jurga, J. Kałkowska i in., Projektowanie systemów..., s. 34. 
4) język wyrażania treści (najczęściej ojczysty);

5) hipertekstowość (interaktywny dostęp do informacji z każdego komputera na świecie, istnienie linków na stronach WWW odsyłających do innych stron);

6) multimedialność (współistnienie informacji w postaci dźwięku ruchomych obrazów, tekstu fotografii, grafiki i możliwość ich dystrybucji, przetwarzania oraz kopiowania i archiwizacji);

7) globalna prezentacja;

8) aktualność (w granicach błędu dopuszczonego przez użytkownika);

9) wiarygodność (dzięki możliwości ustalenia pochodzenia informacji);

10) bezpieczeństwo (zapewnione, gdy dostawca i odbiorca informacji znają zagrożenia i przestrzegają zasad ochrony informacji) ${ }^{33}$.

\section{ZARZĄDZANIE INFORMACJĄ}

Dostępność zasobu informacyjnego zależy od możliwości szybkiego wyszukania pożądanej informacji, dlatego też niezbędne jest zarządzanie informacją. Konieczność zarządzania informacją wystąpiła $w$ warunkach społeczeństwa informacyjnego, posiadającego, wytwarzającego i potrzebującego bardzo dużej kolosalnej ilości informacji. Zarządzanie informacją jest spowodowane potrzebą przechowywania zasobów informacji, ich przetwarzania oraz udostępniania. Celem zarządzania informacją jest dostarczanie informacji dla organizacji zgodnie z jej potrzebami, niezbędnych do podejmowania decyzji i rozwiązywania zaistniałych problemów.

Termin „zarządzanie informacją” pojawił się w latach siedemdziesiątych XX wieku. Jego popularność była związana z prawdziwą rewolucją technologiczną, jaka dokonywała się w masowym, komputerowym przetwarzaniu danych. Z czasem, gdy informacja była już wyraźnie traktowana jako jeden z zasobów strategicznych, niektórzy uczeni przewidywali, że informacja będzie jednym z najistotniejszych zasobów przedsiębiorstwa. Będzie podstawą planowania i podejmowania decyzji. Będzie wykorzystywana do pomiaru efektywności i zyskowności. Innymi słowy - będzie traktowana jako aktywa ${ }^{34}$.

Problematyka zarządzania informacją w najnowszych opracowaniach w opinii specjalistów przedstawiana jest jako podstawowa funkcja zarządzania w organizacji, której rolą jest pozyskiwanie, składowanie oraz dostarczanie właściwej informacji, właściwym osobom, we właściwym czasie.

Zdaniem Małgorzaty Pańkowskiej zarządzanie informacją obejmuje identyfikację, analizę dostępnej i koniecznej informacji oraz procesów jej wytwarzania, a następnie planowanie i kontrolę działań dla rozwoju tych zasobów, a także procesów przetwarzania dla celów organizacji ${ }^{35}$. Zarządzanie informacją to wypełnianie funkcji planowania, kierowania, koordynacji i kontroli odnoszących się do określania potrzeb informacyjnych, opracowywania, przesyłania, gromadzenia i przygotowywania informacji niezbędnych do osiągania celów przez organizację - dotyczy zarządzania zasobami informacyjnymi, zarządzania bankiem danych i technologią informacyjną ${ }^{36}$.

${ }^{33}$ T. Ciesielczyk, G. Watras, Zasoby informacyjne Internetu [w:] Informacja w społeczeństwie XXI wieku, red. M. Rószkiewicz, E. Wędrowska, Warszawa 2005, s. 228-229.

${ }^{34} \mathrm{~J}$. Unold, Zarządzanie informacją w cyberprzestrzeni, Warszawa 2015, s. 59.

${ }^{35}$ M. Pańkowska, Zarządzanie zasobami informatycznymi, Warszawa 2001, s. 16.

${ }^{36}$ R. Borowiecki, J. Czekaj (red.), Zarzqdzanie informacją i komunikacja w organizacjach gospodarczych i instytucjach sektora publicznego, Torun 2012, s. 29. 
Według autorów Business Dictionary zarządzanie informacją polega na zastosowaniu technik zarządzania w procesie pozyskiwania informacji, przekazywania jej wewnątrz i na zewnątrz organizacji oraz przetwarzaniu w celu umożliwienia menedżerom podejmowania szybszych i lepszych decyzji ${ }^{37}$. Podobne ujęcie prezentują autorzy Encyklopedii zarządzania, którzy uważają, że na zarządzanie informacjami składają się:

1) działania tworzące funkcję informacyjną przedsiębiorstwa, tj. pozyskiwanie informacji, przetwarzanie informacji, dyfuzja informacji;

2) działania w ramach płaszczyzn (technologicznej, organizacyjnej, zasobów ludzkich) wpływających na realizację tej funkcji ${ }^{38}$.

W wyniku analizy definicji terminu można zauważyć pewne elementy wspólne, charakterystyczne i uznać je za typowe etapy zarządzania informacją. Są to:

1) identyfikacja potrzeb informacyjnych;

2) pozyskiwanie informacji;

3) organizacja i magazynowanie informacji;

4) tworzenie produktów i usług informacyjnych;

5) dystrybucja informacji;

6) wykorzystanie informacji i zachowania adaptacyjne całej organizacji ${ }^{39}$.

\section{PODSUMOWANIE}

W dobie społeczeństwa informacyjnego dostęp do informacji, jej posiadanie stał się dla organizacji środkiem do rozwoju i przetrwania, zasobem strategicznym, za pomocą którego można zdobyć konkretne korzyści i wysoką pozycję. Do zarządzania organizacją potrzeba coraz więcej informacji. Rozwój technologii informacyjnych, coraz bardziej złożone warunki funkcjonowania organizacji, traktowanie informacji jako kapitału organizacji przesądzają o potrzebie i niezbędności zarządzania informacją.

Zarządzanie informacją jest aktualnym i bardzo ważnym zagadnieniem. Zarządzanie informacjami jako ważna funkcja nowoczesnej organizacji jest koniecznością i wyzwaniem, przed którym współczesne społeczeństwo informacyjne stawia organizację. Podstawą istnienia i rozwoju każdej organizacji jest kształtowanie określonych zasobów informacyjnych postrzeganych w kategoriach zasobów strategicznych, dlatego zarządzanie informacją ma na celu planowanie, organizowanie, kierowanie i kontrolę obiegu informacji w organizacji w trakcie procesów informacyjnych - gromadzenia, przechowywania, przetwarzania i udostępniania. Najważniejszym celem zarządzania informacjami w organizacji jest dobra komunikacja i większa decyzyjność, wynikająca z efektywnego i racjonalnego wykorzystania informacji do podejmowania decyzji.

\section{LITERATURA}

[1] Adair A., Podejmowanie decyzji, Wydawnictwo Petit, Warszawa 1998.

[2] Adamczyk A., Jurga A., Kałkowska J. i in., Projektowanie systemów informacyjnych zarządzania, Wydawnictwo Politechniki Poznańskiej, Poznań 2010.

${ }^{37}$ Business Dictionary, http://www.businessdictionary.com/definition/information-management. html (dostęp: 01.09.2017 r.).

38 J. Unold, Zarzadzanie informacja..., s. 63.

${ }^{39}$ C.W. Choo, Information Management for the Intelligent Organization: The Art of Scanning the Environment. Medford 2002, s. 24. Cyt. za J. Unold, Zarzadzanie informacja..., s. 60. 
[3] Berman C., Informacja $i$ aspekty komunikacji, „Zagadnienia Naukoznawstwa” 1991, nr 3-4.

[4] Borowiecki R., Czekaj J. (red.), Zarządzanie informacja i komunikacja w organizacjach gospodarczych i instytucjach sektora publicznego, Dom Organizatora, Torun 2012.

[5] Business Dictionary, http://www.businessdictionary.com/definition/information-management.html.

[6] Ciesielczyk T., Watras G., Zasoby informacyjne Internetu [w:] Informacja w spoteczeństwie XXI wieku, red. M. Rószkiewicz, E. Wędrowska, Oficyna Wydawnicza SGH, Warszawa 2005.

[7] Choo C.W., Information Management for the Intelligent Organization: The Art of Scanning the Environment. ASIST Monograph Series, Medford 2002.

[8] Czekaj J. (red.), Podstawy zarządzania informacja, Wydawnictwo Uniwersytetu Ekonomicznego w Krakowie, Kraków 2012.

[9] Czermiński A., Czerska M. i in., Zarządzanie organizacjami, Towarzystwo Naukowe Organizacji i Kierownictwa, Toruń 2001.

[10] Flakiewicz W., Informacyjne systemy zarzadzania. Podstawy budowy i funkcjonowania, Państwowe Wydawnictwo Ekonomiczne, Warszawa 1990.

[11] Forlicz S., Informacja w biznesie, Polskie Wydawnictwo Ekonomiczne, Warszawa 2008.

[12] Kasprzyk T. (red.), Cybernetyka zarzadzania w systemach ekonomicznych, PWN, Warszawa 1971.

[13] Krupski R., Podstawy organizacji i zarzadzania, Wydawnictwo I-BiS, Wałbrzych 1997.

[14] Kurnal J., Zarys teorii organizacji zarzadzania, PWE, Warszawa 1969.

[15] Lesca E., Lesca H., Gestion de Information, Litec, Paris 1995.

[16] Martyniak Z. (red.), Elementy zarzadzania informacja i komunikacja $w$ przedsiębiorstwie, Wydawnictwo Akademii Ekonomicznej, Kraków 1997.

[17] Materska K., Informacja w organizacjach spoteczeństwa wiedzy, Wydawnictwo Stowarzyszenia Bibliotekarzy Polskich, Warszawa 2007.

[18] Nowicki A., Sitarska M., Procesy informacyjne w zarządzaniu, Wydawnictwo Uniwersytetu Ekonomicznego we Wrocławiu, Wrocław 2010.

[19] Okoń W., Stownik pedagogiczny, PWN, Warszawa 1992.

[20] Oleński J., Standardy informacyjne $w$ gospodarce, Wydawnictwo Uniwersytetu Warszawskiego, Warszawa 2000.

[21] Pańkowska M., Wiedza i komunikacja $w$ innowacyjnych organizacjach. Komunikacja elektroniczna, Wydawnictwo Uniwersytetu Ekonomicznego w Katowicach, Katowice 2011.

[22] Pańkowska M., Zarządzanie zasobami informatycznymi, Difin, Warszawa 2001.

[23] Penc J., Sztuka skutecznego zarzadzania, Oficyna Ekonomiczna, Kraków 2005.

[24] Potocki A., Winkler R., Żbikowski A., Techniki komunikacji w organizacjach gospodarczych, Difin, Warszawa 2003.

[25] Roman W.K., Podstawy zarzadzania informacja, Wydawnictwo Naukowe Uniwersytetu Mikołaja Kopernika, Toruń 2012.

[26] Simon H., Podejmowanie decyzji kierowniczych. Nowe nurty, PWE, Warszawa 1982.

[27] Stabryła A., Trzcieniecki J., Organizacja i zarządzanie. Zarys problematyki, PWN, Warszawa 1986.

[28] Stankiewicz J., Komunikowanie się w organizacji, Astrum, Wrocław 1999. 
[29] Stefanowicz B., Informacja, Oficyna Wydawnicza Szkoły Głównej Handlowej, Warszawa 2010.

[30] Stefanowicz B., Informacyjne systemy zarzązania. Przewodnik, Szkoła Główna Handlowa w Warszawie, Warszawa 2007.

[31] Unold J., Zarzadzanie informacja w cyberprzestrzeni, PWN, Warszawa 2015.

[32] Weiss E. (red.), Podstawy i metody zarzadzania. Wybrane zagadnienia, Vizja Press, Warszawa 2008.

[33] Wojciechowska-Filipek S., Zarządzanie jakościa informacji w organizacji zhierarchizowanej, Wydawnictwo CeDuWu, Warszawa 2015.

\section{INFORMATION MANAGEMENT IN DECISION-MAKING PROCESS OF ORGANIZATION}

The society we live in - information society - reflects the most important feature of social and economic changes. These are the processes of creating and gathering the information. Nowadays information is the most crucial source and creating, gathering and passing the information is described as a fundamental social and economic activity. Growing importance of the information as the economic source and component of competitiveness makes the information essential for effective functioning and organization development. Information which is valuable and gained in the right time increases confidence in making an accurate decision.

Working over information is very often time-consuming for decision-makers. The manager is often badly informed because of the information overload. As far as management is concerned, the decisive point is not creating, gathering and passing the information but its analysing and filtering.

Communicating is concerned to be as one of the most essential phases of the management cycle. It is perceived as an appropriate information cycle within the organization as well as information exchange with the environment. Communicating is connected with all management elements and effective communicating assures achieving aims by the organization. The decision-making process takes place in the system, which is often called the information and decision system. This system includes all processes of delivering accurate, prompt and needful information to the decision-makers, allowing to make decisions, which influence the efficiency of organization functioning.

The aim of the following article is an attempt to systematize the case of information management in organization. The article contains basic concepts referring to information and communication in decision-making processes of organization. The role of the information in management and selected aspects of information management were presented in this article.

Keywords: information, communicating, management, information management.

DOI: 10.7862/rz.2017.mmr.28

Tekst złożono w redakcji: październik 2017 r.

Przyjęto do druku: grudzień 2017 r. 